JEL Classification: C43, L63, L86, L96, J24, 010

DOI: 10.15587/2312-8372.2019.188751

\section{Grytsulenko S., Zakharchenko $\mathbf{L}$.}

\title{
DEVELOPMENT OF COMPARATIVE ASSES5MENT METHOD OF DIGITAL ECONOMY BASED ON THE INTEGRAL INDEX
}

Об’єктом дослідження є процес статистичного та економічного вимірювання цифрової економіки. Одним з найбільш проблемних місць дослідження є теоретичне обгрунтування підходу до визначення національного індексу розвитку цифрової економіки в умовах початкового етапу цифрової трансформаціі сочіально-економічних відносин в Україні.

У процесі дослідження використовувався метод системного аналізу для виявлення проблем і напрямків вдосконалення цифрової статистики в Україні, вивчення трактування поняття цифрової економіки, в тому числі з позицї базових показників. Методом узагальнення проведена систематизація цифрової індустрії Украйни по видах економічної діяльності національного класифікатора, а також міжнародних індексів цифрової економіки по напрямках ї оцінки. Із застосуванням евристичного методу розроблена методика порівняльної оцінки цифрової економіки на основі інтегрального індексу. Визначення напрямків практичного застосування і подальшого розвитку останнього отримано логічним методом дослідження. За результатами дослідження запропоновано національний індекс розвитку цифрової економіки, що синтезує такі окремі індекси:

- розвиненості цифрової інфраструктури;

- цифровізацї сочіально-економічної системи;

- иифрової трансформацї соціально-економічної системи.

Систематизовані кількісні та якісні показники оцінки цифрової економіки з позицї базових основ ї розвитку.

Такий підхід до визначення інтегрального індексу обумовлений низьким рівнем розвитку цифрової інфраструктури та цифрового сектору економіки України на сучасному етапі, необхідністю створення базових умов цифрової трансформаціӥ за рахунок використання нових інформаційно-комунікаційних технологій.

Розроблена методика виступає інструментом раціоналізащї рішень цифрової політики в реалізацї національної стратегї цифрового розвитку в умовах переходу України до повноцінної цифрової економіки. ї перевага полягає у можливості всебічної (технологічної, економічної, сочіальної) оцінки ступеня розвитку цифрової економіки в країні, що знаходиться на початковому етапі цифрової трансформації. Запропонований оцінний інструментарій служить основою для подальшого його розвитку з позицї повного комплексу чинників (умов) цифрової економіки (цифрових і нецифрових) та иифрових ефектів.

Ключові слова: цифрова економіка, цифровий сектор економіки, цифрова трансформація, інтегральна оцінка, стратегія цифрового розвитку.

Received date: 11.09.2019

Accepted date: 04.10.2019

Published date: 30.12 .2019
Copyright (C) 2019, Grytsulenko S., Zakharchenko L. This is an open access article under the CC BY license (http://creativecommons.org/licenses/by/4.0)

\section{Introduction}

In the new round of the digital revolution, one of the national development goals of most world countries is the widespread adoption of digital technologies in the economy and social sphere. It is digitalization, as the effective use of the capabilities of иonline and new digital technologies by all participants in the economic system of any level that will determine its international competitiveness in the near future.

Today, the digitalization of the world economy is characterized by positive dynamics and significant volume. So, according to experts in [1], the share of the digital economy (DE) in the world economy is about $5 \%$ of world GDP. At the same time, most of it is concentrated in the countries of the global North, and high growth rates (10-25\% per year) are provided by the countries of the global South, which already in 2020 will increase the share of DE in world GDP to $25 \%$.

The establishment and development of DEs is one of the priority areas for leading countries, including the USA, Great Britain, Germany, South Korea, China and others, which are systematically and successfully implementing the «digital development agendas». The DE basis is information and communication technologies (ICT), the 
widespread use/consumption of which provides cardinal transformations in all spheres of human life, including in the economy [2]. Noting the growing contribution of the ICT sector to the global economy, let's point out its low ability to serve as a source of economic growth in Ukraine, due to negative development trends identified in the course of the previous assessment [3, 4].

Taking into account the DE significant potential for developing countries in the form of economic growth, the issues of its assessment are becoming of paramount importance for Ukraine in the context of the implementation of the national Digital Development Concept [5].

Various aspects of DE are reflected in modern works [6, 7]. Recently, much attention has been paid to the DE assessment in the international rating system as a source of information about the potential and dynamics of its development in countries and regions. At the same time, existing techniques often assess only one, for example, the technical side, ignoring either the social or economic dividends of such a complex and complex phenomenon as DE. This reduces the objectivity of assessing its development. Let's also note the importance of taking into account the peculiarities of the modern development of a particular country in order to identify and eliminate problems in the field of DE based on the use of appropriate assessment tools. The growing economic importance of DE on the one hand, along with the need to improve the information-methodological base of its measurement on the other hand, determined the choice of the topic of this research. Therefore, it is relevant to study the problems and difficulties of measuring the DE, the development of assessment tools that are adequate to the tasks of managing digital transformation processes at the national level.

Thus, the object of research is the process of statistical and economic measurement of DE. And the aim of research is development of a methodology for the DE comparative assessment based on the integral index as an indicator of the success of the implementation of the national strategy for the digital development of the economy and society in modern conditions.

\section{Methods of research}

The information material selected scientific papers and statistical information in the DE field. To ensure the validity of the research results, scientific methods are used, in particular system analysis - to identify problems and directions for improving digital statistics in Ukraine, to study the interpretation of the DE concept. A generalization method is used to systematize the digital industry of Ukraine according to the types of economic activity of the national classifier, as well as the international DE indices according to the directions of its assessment. Using the heuristic method, a technique has been developed for the DE comparative assessment based on the integral index. The determination of the directions of practical application and further development of the latter is obtained by the logical method of research.

\section{Research results and discussion}

3.1. A critical analysis of current $D E$ monitoring practices. The difficulties in DE measuring are caused by various reasons, including its substantial aspect: the existence in a hybrid (virtual-real) world [8] and the techno-digital nature of economic relations [9]. Among the obstacles, let's also note the problem of quality data for the successful implementation of state digital policy.

So, in the DE context, the demand for the volume and quality of information about socio-economic phenomena in society is changing, and statistical and economic assessments of its development processes are required. However, the official statistics of Ukraine do not meet the needs of interested users due to incomplete observations of the digitalization process of various aspects of the functioning of the economy and human life. Current monitoring practice is limited to measuring individual parameters of the development of info-communications and the information society, scattered across many statistical publications [10]:

- information infrastructure «State and development of communication in Ukraine»;

- use of ICT funds by individuals and legal entities: «State and development of communication in Ukraine», «Use of ICT in enterprises»;

- economic activities of the subjects of the Information and Telecommunications services industry as an independent monitoring object: «Transport and communications of Ukraine», «Activities of business entities», «Capital investments in Ukraine», «Foreign trade of goods and services in Ukraine», «Foreign trade of Ukraine», «Scientific and innovative activity of Ukraine».

While the indicators for the development of the production and trade segments of the ICT sector are presented mainly in the composition of industries that include similar types of economic activity. An exception is capital investment, measured by all codes of economic activities introduced by the national classification of Ukraine KVED-2010 (classifier of types of economic activity) [11]. It follows that there are no public statistics on ICT as an integrated economic sector in Ukraine. In addition, attention is not paid to the statistical assessment of the use of ICT in government and the socio-cultural sphere, online interaction of the population with government, and the measurement of electronic commerce is limited by quantitative parameters.

Thus, the available information, instead of a single compendium on statistics of the information society and DEs, is dispersed across various publications, and its composition only partially characterizes the development of DEs.

The importance of improving the statistical measurement of $\mathrm{DE}$ in the above areas is obvious today. Among the promising directions for the development of DE monitoring, as shown by the analysis of information sources on the research topic [12-14], the following can be distinguished:

- the formation of the DE conceptual apparatus, the development of a classification of digital technologies, a system of statistical indicators and data collection tools; - training for DE and digital literacy of the population; - research and development in the field of digital technologies, as well as innovations related to digital technologies;

- patent protection and transfer of digital technologies;

- trust and security in the digital environment;

- transformational shifts under the influence of digital technologies in the national economy and society (economic growth, employment, quality of services, social welfare, etc.);

- the country's involvement in the global DE. 
The formation of an information base based on traditional and alternative data sources, capable of providing interested users with quality products for educational, analytical, research, and managerial activities, is the most important task of digital statistics.

3.2. Research of approaches to the $\mathrm{DE}$ economic measurement. DE measurement scales is also complicated by the variety of approaches to determining its boundaries, which complicates the comparative analysis.

So, the DE concept in the broad sense of the word goes beyond the sectors generating digital technologies, covering a much larger area of economic and economic activity, including the «least digital» sectors of the economy (mining, agriculture, construction, utilities). As noted in the DE project [15], as scientific and technological progress progresses, the digital nature of the economy determines how much it relies on digital technologies to increase productivity and improve growth potential in a wider spectrum. That is, DE covers subjects of all sectors of the economy.

In a narrow sense, DE includes completely new types of economic activity that did not exist before the advent of digital technology. It is possible to talk about electronic business, digital services, platform economics, the economy of «joint consumption», the economy of «joint earnings» as emerging digital business models.

Whereas its basic indicators are the size and growth of industries in the digital economy sector (DES). DES covers the types of economic activities in the field of ICT (ICT sector) and related types of economic activity (content and mass media sectors) (Fig. 1).

Types of economic activity in the framework of the national classifier, in particular Ukraine, correspond to each DES industry (Table 1).

By solving the question «what, on the basis of what and how to measure?», it is possible to ensure objectivity in assessing the DE development in solving the problems of its study and management.

Today, in practice of overcoming the lag and increasing the competitive advantages of national economies, international ratings are widely used, including in the DE field. DE development level and the global image of a country are measured on the basis of various composite indices that integrate individual sub-indices and their corresponding indicators.

World-famous rankings are based on the following indices (Table 2).
A detailed analysis of most of them (10) in the context of the methodology of formation and calculation, advantages and disadvantages is presented in [16].

Another component of the DE measurement is the Global Cybersecurity Index, which tracks the level of countries' obligations in such areas as legislative, technical and organizational measures, capacity development and international cooperation through relevant sub-indices. The rating characterizes the success of national structures in ensuring the appropriate level of preparedness of the cybersecurity system for the population, business and the state as a whole.

Among the ratings, one way or another characterizing the DES, are also the Production Drivers Index and the Global Competitiveness Index.

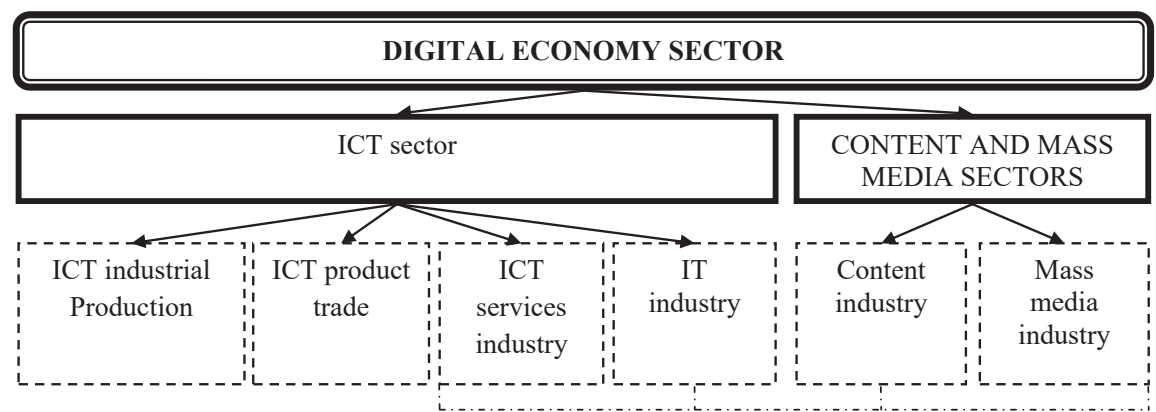

$\begin{array}{ccc}\begin{array}{c}\text { DES production } \\ \text { segment }\end{array} & \begin{array}{c}\text { DES trade } \\ \text { segment }\end{array} & \text { DES service segment }\end{array}$

Fig. 1. The digital industry as an integrated economic sector

Table 1

Digital industry according to KVED-2010*

\begin{tabular}{|c|c|}
\hline Industries & Types of economic activity \\
\hline \multicolumn{2}{|r|}{ ICT sector } \\
\hline $\begin{array}{l}\text { ICT } \\
\text { Industrial } \\
\text { Production }\end{array}$ & $\begin{array}{l}\text { - manufacture of electronic components and boards (26.1); } \\
\text { - manufacture of computers and peripheral equipment (26.2); } \\
\text { - manufacture of communication equipment (26.3); } \\
\text { - the production of household electronic equipment for the reception, recording and repro- } \\
\text { duction of sound and images (26.4); } \\
\text { - production of magnetic and optical data carriers (26.8); } \\
\text { - manufacture of fiber optic cables (27.31) }\end{array}$ \\
\hline $\begin{array}{l}\text { ICT Product } \\
\text { Trade }\end{array}$ & $\begin{array}{l}\text { - wholesale of information and communication equipment (46.5); } \\
\text { - retail sale of information and communication equipment in specialized stores (47.4) }\end{array}$ \\
\hline $\begin{array}{l}\text { ICT services } \\
\text { Industry }\end{array}$ & $\begin{array}{l}\text { - activities in the field of wired telecommunications (61.1); } \\
\text { - activities in the field of wireless telecommunications (61.2); } \\
\text { - activities in the field of satellite telecommunications (61.3); } \\
\text { - ather activities in the field of telecommunications (61.9); } \\
\text { - repair of computers and communications equipment (95.1) }\end{array}$ \\
\hline IT industry & $\begin{array}{l}\text { - software publishing (58.2); } \\
\text { - computer programming, consulting and related activities (62.0); } \\
\text { - data processing, posting information on web sites and related activities; web portals (63.1) }\end{array}$ \\
\hline \multicolumn{2}{|r|}{ Content and Mass Media sector } \\
\hline $\begin{array}{l}\text { Content } \\
\text { Industry }\end{array}$ & $\begin{array}{l}\text { - production of film and video films, television programs (59.1); } \\
\text { - publication of sound recordings (59.2); } \\
\text { - activities in the field of broadcasting (60.1); } \\
\text { - activities in the field of television broadcasting (60.2); } \\
\text { - the provision of other information services (63.9) }\end{array}$ \\
\hline $\begin{array}{l}\text { Mass media } \\
\text { industry }\end{array}$ & - publishing of books, periodicals and other publishing activities (58.1) \\
\hline
\end{tabular}

Note: ${ }^{*}$ - built on the basis of data [11] 
World rankings of digital transformation of economics and society

\begin{tabular}{|c|c|c|}
\hline No. & Index name & Index developers \\
\hline 1 & ICT Development Index (IDI) & \multirow{2}{*}{ International Telecommunication Union (ITU) } \\
\hline 2 & Global Cybersecurity Index (GCI-ITU) & \\
\hline 3 & Digital Economy and Society Index (DESI) & European Commission \\
\hline 4 & World Digital Competitiveness Index (WDCI) & Swiss Business School IMD \\
\hline 5 & Digital Evolution Index (DEI) & Taft University (USA), MasterCard \\
\hline 6 & Digital Economy Index (BCG e-Intensity Index) & The Boston Consulting Group (BCG) \\
\hline 7 & Network Readiness Index (NRI) & World Economic Forum (WEF), World Bank (WB), INSEAD International Business School \\
\hline 8 & E-Government Development Index (EGDI) & \multirow{2}{*}{ United Nations Department of Economic and Social Development (UNDESA) } \\
\hline 9 & Electronic Participation Index (EPI) & \\
\hline 10 & Global Connectivity Index (GCI-Huawei) & Huawei \\
\hline 11 & Global Innovation Index (GII) & $\begin{array}{l}\text { Cornell University (USA), INSEAD International Business School, World Intellectual Property Organiza- } \\
\text { tion (WIPO) }\end{array}$ \\
\hline 12 & Driver Production Index (DPI) & \multirow{2}{*}{ World Economic Forum (WEF) } \\
\hline 13 & Global Competitiveness Index (GCI-WEF) & \\
\hline
\end{tabular}

So, DPI contains the «Technology and Innovation» driver as a sub-index, combining indicators of the development of ICT infrastructure, their use by the population, the impact of ICT on the development of new services, products and the importance of GCI-ITU. Elements of the GCI-WEF structure, as a comprehensive assessment of a country's ability to provide stable economic growth rates in the medium term, are ICT assessment indicators in terms of the level of infrastructure development and ICT use by the population.

Common to the 13 given indices is the presence in their composition of indicators of ICT infrastructure development as the basis for successful digitalization of the economy and society (Table 3 ). More than half ( 7 - GCI-ITU, WDCI, DEI, NRI, GCI-Huawei, GII, GCI-WEF) of all indices assess both the institutional framework and the innovative digitalization environment. Only 3 indexes
(DESI, e-Intensity, NRI) measure the affordability of ICT services. The level of education of the population and the skills of using ICTs are taken into account by the IDI, GCI-ITU, WDCI, e-Intensity, EGDI indices, and the use of the Internet by the population and ICT in business is taken into account by WDCI, DEI, DESI, e-Intensity, NRI, GCI-Huawei, DPI GII. Almost all indices, except IDI, assess the level of accessibility of state electronic services. The level of information security is measured by 4 indexes (GCI-ITU, WDCI, DEI, DPI), and the development of digital technologies - only 1 (GCI-Huawei). Indicators of international cooperation in the field of ICT are included in the structure of the GCI-ITU and DPI indices, while indicators of the impact of ICT on the economy are in the NRI, GCI-Huawei, GII, and on society in the GCI-ITU, NRI, GII, GCI-WEF.

Table 3

Comparative analysis of international development indices of the digital economy in the context of individual groups of indicators

\begin{tabular}{|c|c|c|c|c|c|c|c|c|c|c|c|c|c|}
\hline Group of indicators* & IDI & GCI-ITU & DESI & WDCI & DEI & e-In-tensity & NRI & EGDI & EPI & GCI-Huawei & GII & DPI & GCI-WEF \\
\hline 1 & - & + & - & + & + & - & + & - & - & + & + & - & + \\
\hline 2 & - & + & - & + & + & - & + & - & - & + & + & - & + \\
\hline 3 & + & + & + & + & + & + & + & + & + & + & + & + & + \\
\hline 4 & - & - & + & - & - & + & + & - & - & - & - & - & - \\
\hline 5 & + & + & - & + & - & + & - & + & - & - & - & - & - \\
\hline 6 & + & + & - & + & - & + & - & + & - & - & - & - & - \\
\hline 7 & - & - & + & + & + & + & + & - & - & - & + & + & - \\
\hline 8 & - & - & + & + & + & + & + & - & - & + & + & + & - \\
\hline 9 & - & + & + & + & + & + & + & + & + & + & + & + & + \\
\hline 10 & - & + & - & + & + & - & - & - & - & - & - & + & - \\
\hline 11 & - & - & - & - & - & - & - & - & - & + & - & - & - \\
\hline 12 & - & + & - & - & - & - & - & - & - & - & - & + & - \\
\hline 13 & - & - & - & - & - & - & + & - & - & + & + & - & - \\
\hline 14 & - & + & - & - & - & - & + & - & - & - & + & - & + \\
\hline
\end{tabular}

Note: ${ }^{*}$ - group of assessment indicators: 1 - institutional environment; 2 - innovative environment; 3 - ICT infrastructure development; 4 - affordability of ICT services; 5 - education of the population; 6 - practical skills in the use of ICT; 7 - directions of Internet use by the population; 8 - use of ICT in business; 9 - access to state electronic services; 10 - information, including cybersecurity; 11 - development of digital technology; 12 - international cooperation in the field of ICT; 13 - ICT impact on the economy; 14 - ICT impact on society 
Thus, the institutional, technological and economic assessments of the regulatory and research base, the use of ICTs in business and information security to a greater extent combine the indices GCI-ITU, WDCI, DEI, NRI, GCI-Huawei, GII, DPI, GCI- WEF. Indices IDI, DESI, e-Intensity, EGDI, EPI are socially oriented.

Assessing mainly the development of the information society, they do not reflect the level of digitalization of the entrepreneurial sector of the economy.

As the author of [16] rightly notes, the international DE indexes, which mostly assess the technical side of development, do not take into account the particularities of each country, adjusting its indicators to the calculated requirements, which is their drawback. In this regard, a methodology is proposed for assessing DE based on a composite index to identify problem areas of its development in the Republic of Belarus. So, the country's rating is formed in the form of a three-level model (the country's readiness to introduce digital technologies, the intensity of their use in the national economy and the impact on gross national income). A composite index includes five sub-indexes of varying weight: $20 \%$;

1) quality of ICT infrastructure and Internet access -

2) Internet usage intensity - $15 \%$;

3) human capital - $20 \%$;

4) digitalization of the economy - $20 \%$;

5) effectiveness of the digital transformation of the economy $-25 \%$.

Moreover, each sub-index corresponds to a group of indicators based on data from national statistics and international organizations.

So, a comparative analysis of global digital ratings indicates an already formed extensive apparatus for assessing DEs based on composite indices that mainly study the ICT infrastructure and their use by the population. This is not enough to identify the problem areas of the digital development of the economy of a particular country as a complex phenomenon. A hierarchical approach to the DE assessment based on a three-level model is called upon to supplement the existing gap as a tool for identifying digitalization problems, both in the field of implementation and application of digital technologies, and their impact on the national economy, in particular, Belarus.

At the same time, the methodology for assessing DEs developed in [16] is not without drawbacks. So, it does not take into account the social dividends of DE development, which narrows the possibilities of the integrated index for a comprehensive assessment of the impact of digital ICT on all spheres of human life and activity in the modern era.
A more precise definition of the boundaries of the economic sector as an object of DE integrated assessment is also required. Thus, the effectiveness of the digital transformation within the framework of the methodology is determined by the estimates of the ICT sector without taking into account the activities of the content and mass media sectors, which are DES integral element. In general, the methodology is aimed at assessing the contribution of the ICT sector to the national economy that is measuring basic DE indicators in the Republic of Belarus.

This approach to determining the DE development index is also relevant for modern Ukraine with its low level of information and communication development. The reason for this is the insufficient level of development of the ICT infrastructure, the ICT sector, as well as the use of digital ICT in the economy and society, which is insufficient for the transition to a full-fledged DE, which is confirmed by previous estimates [17]. Noting the development of digital infrastructure and central digital centers as the basic conditions for digital transformation through the use of digital ICTs, it seems advisable to determine the aggregate assessment of the DES development level based on the corresponding national index.

3.3. Determination of the aggregate assessment of the DES development level based on the national index. Thus, the national DE development index (NDEDI) at the first stage of the development of the toolkit synthesizes its technological, economic and social indicators based on monitoring information available today. In this case, the assessment criteria are:

- development level of digital infrastructure in the context of connection to communication networks, accessibility of communication services and information security;

- digitalization level of the socio-economic system in the context of the use of digital ICT by the population, business and the state;

- digital transformation level of the socio-economic system in the context of the economic and DES social influence. A key feature of the DES is the use of information as the main and strategic factor in production, benefiting not only owners, but also users.

Accordingly, NDEDI includes three indices (Fig. 2).

In turn, each of the private indices contains a specific set of sub-indexes and the corresponding quantitative and qualitative indicators that are most significant for characterizing the DE from the position of the basic foundations of development (Table 4).

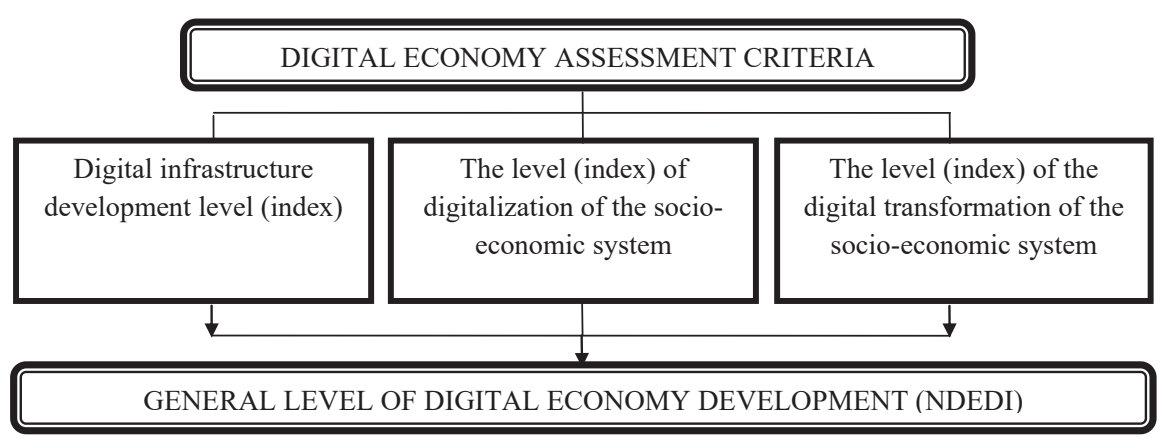

Fig. 2. Criteria for assessing the level of the digital economy development 
The system of indicators for measuring DE from the position of the basic foundations of development

\begin{tabular}{|c|c|}
\hline Indexes/Sub-indexes & Indicators \\
\hline & Digital infrastructure development index \\
\hline \multirow{5}{*}{$\begin{array}{l}\text { Connection to commu- } \\
\text { nication networks }\end{array}$} & The number of fixed broadband access ${ }^{1}$ Internet subscribers рег 100 inhabitants \\
\hline & The number of subscribers of mobile broadband to the Internet per 100 inhabitants \\
\hline & Household coverage of broadband Internet access, \% \\
\hline & Coverage of the population by mobile cellular networks (3G, 4G), \% \\
\hline & International Internet bandwidth, bps per user \\
\hline \multirow{2}{*}{$\begin{array}{l}\text { Availability of com- } \\
\text { munication services }\end{array}$} & The price of fixed broadband access to the Internet, \% GNI per capita ${ }^{2}$ \\
\hline & The price of mobile broadband access to the Internet, \% GNI per capita ${ }^{2}$ \\
\hline \multirow{3}{*}{ Information Security ${ }^{3}$} & The population using information security tools (encryption tools, electronic signature tools, etc.), \% \\
\hline & Enterprises using information protection tools, \% \\
\hline & Bodies of state power and local self-government (hereinafter геferred to as the authorities) using information protection tools, \% \\
\hline \multirow{4}{*}{$\begin{array}{l}\text { Use of digital ICT by } \\
\text { citizens and consumers }\end{array}$} & Digitalization Index of Socio-Economic System $^{4}$ \\
\hline & The share of Internet users in the total population, \% \\
\hline & $\begin{array}{l}\text { The population using the Internet in social activities (to receive educational, medical and public services, to participate in online } \\
\text { polls regarding social or political life, communicate on social networks, etc.), \% }\end{array}$ \\
\hline & The population using the Internet in economic activities (for remote work, job search, online purchase, financial transactions, etc.) \\
\hline \multirow{6}{*}{$\begin{array}{l}\text { Use of digital ICT } \\
\text { business }\end{array}$} & Enterprises using broadband Internet access, \% \\
\hline & Enterprises using cloud computing services (for financial statements and cloud telephony, hosting, etc.), \% \\
\hline & $\begin{array}{l}\text { Enterprises using traditional ICTs for doing business (electronic exchange systems - EES, enterprise resource management sys- } \\
\text { tems - ERM, customer relations - CRM, supply chains - SCM, and the presence of a website), \% }\end{array}$ \\
\hline & $\begin{array}{l}\text { Enterprises using new ICTs in business (Big Data Technologies - Big Data, Distributed Registry Systems, Internet of Things, Cloud } \\
\text { Technologies - Cloud Computing, etc.), \% }\end{array}$ \\
\hline & Enterprises using digital ICTs for commercial purposes (e-commerce, online banking, online broking), \% \\
\hline & Enterprises using ICT for online interaction with authorities, \% \\
\hline \multirow{6}{*}{$\begin{array}{l}\text { Use of digital ICT by } \\
\text { state }\end{array}$} & Authorities with broadband Internet access, \% \\
\hline & Authorities using cloud computing services, \% \\
\hline & Authorities using traditional ICTs in governance \\
\hline & Authorities using new ICTs in the management system \\
\hline & Types of online services provided by authorities to the population and business, \% \\
\hline & Online services provided by authorities to the population and business for the year, \% \\
\hline \multirow{6}{*}{ DES economic impact } & Index of Digital Transformation of Socio-Economic System \\
\hline & DES share (hereinafter in the context of subsectors) in GDP, \% \\
\hline & DES share in the total volume of export/import of goods/services, \% \\
\hline & DES share in the total volume of investments in fixed assets, \% \\
\hline & The share of innovative products of CSE in the total volume of sales of enterprises, \% \\
\hline & DES share in the growth of productivity of social labor, \% \\
\hline \multirow{3}{*}{ DES social impact } & DES share in the total labor force, \% \\
\hline & DES share in the creation of new jobs, including in other sectors of the economy, \% \\
\hline & DES influence on citizens' access to basic services 5 (medical, educational, financial, etc.) \\
\hline
\end{tabular}

Note: 1 - broadband access; 2 - GNI per capita - gross national income per capita; 3 - in the absence of national statistics, it is possible to use the values of the Sub-Index of the technical aspects of cybersecurity GCI-ITU; 4 - it is possible to use the values of the 5ub-index for the ICT use by citizens, business, and the state for the NRI socio-economic development; 5 - it is possible to use the values of the Social Progress Index or its individual indicators

The total value of NDIDE is calculated as the arithmetic average of its three indices, reflecting individual estimates of the overall process of DE development. In this case, private indices are calculated as the arithmetic average of the corresponding sub-indexes, and sub-indexes are calculated as the arithmetic average of the values of the normalized indicators included in each of them.

\section{Conclusions}

So, when determining the research and development center, let's proceed from the existing positive experience in the field of DE measuring, the presence of a straightforward relationship between the level of DES development and socio-economic growth, sufficient simplicity of the practical 
application of the calculation method. As well as the significance of the estimates obtained for rationalizing digital policy decisions in implementing the digital development strategy of the economy and society.

NDIDE allows:

- conduct a comparative analysis of the current state and dynamics of the DE development;

- assess the situation with the key conditions for the DE development (digital infrastructure and DES), the digitalization process and the effects of digital transformation under the influence of its driving force - DES; - identify the causes of emerging changes and growth points of digital activity, form directions for further DE development;

- assess the level of implementation of the national digital development strategy, adjust plans for digitalization and digital transformation, make economically sound management decisions.

Thus, the proposed methodology, including measurement tools (national and international monitoring observations), assessment criteria and indicators, acts as a tool for DE managing from the point of view of the basic foundations of development.

Further NDIDE development provides for the following: - expanding the range of tools for information and analytical support of the DE measurement process (for example, expert surveys);

- formation of a full range of factors for the DE development: digital (for example, digital platforms) and non-digital (state digital policy, human capital, innovation, etc.) for a comprehensive assessment of the country's level of readiness for the establishment of a full DE;

- increase in subject areas for assessing the digitalization level of a socio-economic system (for example, the social sphere);

- increase in the number of indicators of digital effects, including new ones, to assess the level of digital transformation of the economy and society, including through the digitalization of other sectors of the economy;

- formation of a system of tools, criteria and indicators for measuring the DE development level in the broad sense of the word.

The research results can be used as a tool for assessing the level of implementation of a digital strategy in the context of Ukraine's transition to a full-fledged DE, as well as a basis for its further development.

\section{References}

1. Bukht, R., Khiks, R., (2018). Opredelenie, kontseptsiia i izmerenie tsifrovoi ekonomiki. Vestnik mezhdunarodnykh organizatsii, 13 (2), 143-172.

2. Striy, L., Orlov, V., Zakharchenko, L. (2019). Economic activity of enterprises of the telecommunication industry in conditions of implementation of the newest technologies. Baltic Journal of
Economic Studies, 5 (1), 207. doi: http://doi.org/10.30525/22560742/2019-5-1-207-213

3. Gritsulenko, S. I., Guseinov, N. (2018). Izmerenie razvitiia sektora IKT v Ukraine. Infrastruktura rinku, 16, 16-25. Available at: http://www.market-infr.od.ua/journals/2018/16 2018 ukr/5.pdf

4. Zakharchenko, L. A. (2010). Diagnostika razvitiia infokommunikatsii kak sostavliaiushchei mezhdunarodnoi konkurentosposobnosti informatsionnoi ekonomiki. Rozvitok metodiv upravlinnia ta gospodariuvannia na transporti, 32, 206-221.

5. Pro skhvalennia Kontseptsii rozvytku tsyfrovoi ekonomiky ta suspilstva Ukrainy na 2018-2020 roky ta zatverdzhennia planu zakhodiv shchodo yii realizatsii (2018). Rozporiadzhennia Kabinetu Ministriv Ukrainy No. 67-r. 17.01.2018. Available at: http:// zakon.rada.gov.ua/laws/show/67-2018-p

6. Beerepoot, N., Lambregts, B. (2014). Competition in online job marketplaces: towards a global labour market for outsourcing services? Global Networks, 15 (2), 236-255. doi: http://doi.org/ 10.1111/glob.12051

7. Ivanov, S. V., Vishnevskii, A. S. (2017). Elektronnye platformy kak instrument modernizatsii ekonomiki Ukrainy. Visnik ekonomichnoi nauki Ukraini, 1, 47-53.

8. Keshelava, A. V. et. al.; Keshelava, A. V. (Ed). (2017). Vvedenie $v$ «TSifrovuiu» ekonomiku. Moscow: VNIIGeosistem, 28.

9. Razvitie tsifrovoi ekonomiki v Rossii kak kliuchevoi faktor ekonomicheskogo rosta $i$ povysheniia kachestva zhizni naseleniia (2018). Nizhnii Novgorod: Professionalnaia nauka, 131.

10. Statystychna informatsiia: publikatsii. Hosudarstvennaia sluzhba statystyky Ukrayny. Available at: http://www.ukrstat.gov.ua Last accessed: 21.05.2019

11. Perelik kodiv vydiv ekonomichnoi diialnosti za natsionalnym klasyfikatorom: Klasyfikatsiia vydiv ekonomichnoi diialnosti DK 009:2010. Hosudarstvennaia fyskalnaia sluzhba Ukrayny. Available at: http://sfs.gov.ua/dovidniki--reestri--perelik/pereliki-/128651.html Last accessed: 21.05.2019

12. Yershova, O. L., Odnovolyk, V. I. (2018). Natsionalna systema tsyfrovoi statystyky yak zasib dlia vymiriuvannia tsyfrovykh transformatsii v ekonomitsi Ukrainy. Statystyka v Ukraini ta sviti: stan, tendentsii ta perspektyoy rozvytku. Kyiv, 128-133.

13. Abroskin, A. S. (2018). Mezhdunarodnyi opyt izmerenii tsifrovoi ekonomiki. Vestnik universiteta, 12, 59-63.

14. Chto takoe tsifrovaia ekonomika? (2019). Trendy, kompetentsii, izmerenie, 82

15. Soputstvuiushchii effekt tsifrovizatsii - izmerenie realnogo vozdeistviia tsifrovoi ekonomiki: issledovatelskii proekt po tsifrovoi ekonomike Huawei Technologies Co., Ltd u Oxford Economics Ltd (2017). Huawei Technologies Co., Ltd, 55.

16. Golovenchik, G. G. (2018). Reitingovyi analiz urovnia tsifrovoi transformatsii ekonomik stran EAES i ES. Tsifrovaia transformatsiia, 2 (3), 5-18.

17. Grytsulenko, S. I., Umanets, O. Y. (2018). The Infocommunications Development of Ukraine under Conditions of the Transition to the Digital Economy. The problems of economy, 4 (38), 49-60. doi: http://doi.org/10.32983/2222-0712-2018-4-49-60

Grytsulenko Svitlana, PhD, Associated Professor, Department of Business Economics and Corporate Management, O. S. Popov Odessa National Academy of Telecommunications, Ukraine, e-mail: gsi0910@ukr.net, ORCID: http://orcid.org/0000-0001-5191-5639

Zakharchenko Lolita, PhD, Professor, Department of Business Economics and Corporate Management, O. S. Popov Odessa National Academy of Telecommunications, Ukraine,e-mail:iem_onaz_new@ukr.net ORCID: http://orcid.org/0000-0001-8771-2729 